\title{
Business Actors Accountability Model in The Criminal Act of Illegal Logging in Bima NTB
}

\author{
Andriadin ${ }^{1 *}$, Absori ${ }^{1}$, Wardah Yuspin ${ }^{1}$ \\ 1 Faculty of Law, Universitas Muhammadiyah Surakarta, indonesia \\ *Correspondence: andriadinbima@gmail.com
}

\author{
ARTICLE HISTORY \\ Received: 15.11.2021 \\ Accepted: 21.12.2021 \\ Published: 27.12.2021

\section{ARTICLE LICENCE} \\ Copyright (C) 2021 The \\ Author(s): This is an \\ open-access article \\ distributed under the \\ terms of the Creative \\ Commons Attribution \\ ShareAlike 4.0 \\ International (CC BY-SA \\ 4.0)
}

\begin{abstract}
The phenomenal of forest destruction in Bima NTB is motivated by various factors, including agricultural factors, policy factors and inter-regional timber trade systems, business development and timber trade is carried out in unlawful ways such as falsification of forest product documents, logging and timber management without a permit. The purpose of this study is to find out the general description of illegal logging crimes in Bima, prevention efforts and the model of accountability for business actors involved in illegal logging crimes in Bima. The method used in this research is empirical legal research with a socio-legal approach and a case approach (legal approach). Types and sources of data in the form of primary data and secondary data. The results of this study indicate that the model of responsibility imposed on business actors who carry out illegal logging, transportation and processing of wood, in the form of imprisonment and additional penalties, if unable to pay the tax, it will be replaced with imprisonment. This can be seen in the decision of the Raba Bima District Court with the number: 231/Pid. B/LH/2020/PN RBI dated 17 June 2020 in the first alternative indictment the Raba Bima District Court sentenced the defendant TF for violating the provisions of chapter 88 verse 1 letter a Jo. Chapter 16 of law no. 18 of 2013 concerning the prevention and eradication of forest destruction.

Keywords: Criminal; Illegal; Logging; Corporate Accountability
\end{abstract}

\section{Introduction}

Indonesia is one of the countries that has a lot of diversity and wealth, where the forest area includes flora and fauna, forests are also a source of human life and become an important component for the environment, therefore the use and management of forest areas must be carried out properly. Social, and economic. Several times there have been changes in forestry laws, but the fact is that crimes againstforests are still ongoing today. According to Absori "from year to year the accumulation of forest destruction and the universe is increasingly un controllable" (Absori, n.d.)

The problem of forest destruction today not only occurs in Indonesia, but also occurs in foreign countries such as Brazil, Africa, Latin America, Democratic Republic of Congo, Meksico and Malasyia. The University of Marland (UMD) and the World Resource Institute (WRI) released data on forest destruction in 2019 where the number of forest destruction in tropical states and Asia reached 3.75 million hectares per year, Brazil with damage rate of about 24.5 million hectares, Indonesia is in second place from Brazil with forest destruction rate of about 9.5 million hectares, then Democratic Congo is third with damage rate of 4.8 million hectares, (Butler, 2020)

The discourse of resistance and eradication of illegal logging has been since 2005 where the United Nations held a referendum and presented several states including Indonesia. In the meeting contained 3 (three) important things, namely to make regulations against illegal logging, prevent the occurrence of illegal timber trade (exportimport) and maintain environmental survival, these steps are projected in the concept of sustainable development for the next few years, (Flejzor, 2005). While in "2009-2014 Tingkonk and Indonesia also signed a Memorandum of Understanding (MOU) as part of efforts to prevent illegal timber trade between Indonesia-Tingkonk countries, which was later contained in the regional Forest Law Enforcementand Governance (FLEG) declaration"(Febrianto, 2019). 
In principle, forest destruction is synonymous with illegal logging activities, where the activity is carried out in unlawful ways such as the transportation of tampa paperwork, illegal logging, and illegal timber trafficking. This type of action does not only involve individuals who involve business actors or corporations engaged in trade and business, even in order to launch a business activity they often build access and communication across power, it is solely to influence the law enforcement system as well as government policy. (Imron Rizki, Safrin Salam, 2019) The access they built certainly has special points on reducing tax costs and the release of road letters. It is not impossible when, Astan Wirya revealed that "the mode of illegal logging crime will not work well without involving workers, the public, bureaucrats, political elites and police officers". (Wirya, 2015)

Business settlement in legal literature is identified as a legal entity or a business entity that is not an incorporated entity. Law No. 7 of 2014 on Trade explains that "business actors are individuals or busi ness entities in the form of legal entities or not legal entities established and domiciled in the jurisdiction of the unitary state of the Republic of Indonesia and conduct business activities in the field of trade" When business actors or business entities commit a criminal act, then discourse that then arises there is a difference of views on the concept of criminal accountability. for business actors / corporations that are legal entities and that are not legal entities. This discourse departs from the theory of legal fiction that assumes that "a collection of business actors / corporations is just an abstraction or imagination that is lived in the form of an in concrete shadow" the legal entity can desire if there is a human who wants it but not in a real form, so the theory of fiction assumes only humans can be punished and sentenced to criminal punishment, (Anjari, 2016).

Seeing the development of crime in the era of globalization that is increasingly sophisticated and organized, the law is not necessarily understood as adherents of the principle of accountability for mistakes for natural human actions alone, but the law must be understood as a dynamic elementand follow the flow of the times. According to The Desimadi \& Nyoman United Day Putra Jaya "the development of new trade and business transactions has begun to leave behind primitive patterns of this also that will affect the development of special crimes in the field of economics and business where this crime is widely developed by business people / corporations"(Silk Day Disemadi, 2019) . Because the subject who commits a crime is not only human but can also be done by a collection of businesses / corporations, business entities are also part of the legal subject. Recognition of business actors as legal subjects can be seen in the Criminal Code (Criminal Code) which regulates individuals, while the collection of businesses / corporations of legal entities and not legal entities are regulated in civil law and laws outside the Criminal Code including the Forestry Law, The Environment Law, trade law, Economic Crime Law, Money Laundering Law, and Criminal Code of Corruption, Thus Indonesia has recognized business entities / corporations as legal subjects both criminal and civil law subjects. With regard to the regulation of legal liability for the actions of business actors / corporations further regulated in the Supreme Court Regulation(Perma) Number 13 of 2016 concerning procedures for handling corporate criminal acts.

Some researchers have previously tried to conduct literature studies related to the concept of legal accountability for actors who come from among entrepreneurs or companies (corporations) as the results of research conducted by M. Amoah \& R.K. where in his research offered that "when the company is controlled by business actors that lead to an act of illegal logging of forests then the concept of accountability that must be applied can be in the form of Corporate Social Responsibility-CSR (corporate social accountability) so that the company can act ethically on the environment and sustainable social security, corporate accountability can also be in the form of compensation and re-greening for the damage caused, (Amoah \& Boateng, n.d.). Septa Candra with his research focus on the criminal responsibility of business actors who commit environmental crimes states that "in order to convict business actors / corporations in law enforcement must be applied multidoorsystem (system of incorporation of several laws) to avoid the escape of perpetrators"(Candra, 2020),

Similarities that can be concluded from the above research with the research that is being conducted there is a discussion on legal accountability for business actors / corporations but the difference that can be developed from this study with previous researches, namely the space and place of research then this research is more focused on the discussion of illegal logging crimes involving business actors in Bima NTB, where the pattern of illegal logging crimes in Bima is dominated by entrepreneurs engaged in the field of inter-regional timber trade some cases of illegal logging such as counterfeiting, the use of without permit areas, shipping and sheltering wood illegally often not processed properly by law enforcementeven the largest contribution of forest destruction is in the Bima NTB region. The question then arises how the type of illegal logging crimes thatoccurred in Bima so far, what 
are the factors that trigger the occurrence of deforestation and forest degradation in Bima, and how legal accountability for actors from among trade businesses who trade timber from Bima illegally.

\section{Methodology}

The type of research that is builtwill be legal-empirical research, this type of research is research that looks at the law forreal, the law is not only understood from the text of the law or regulations alone, but the law must be understood contextually where the law works in society. The data sources in this study are primary data and secondary data. Primary data is data obtained directly both through field surveys and observing social behavior. The primary data in this study is the data obtained from interviews, documentation and observations. Secondary data in this study in the form of books, official documents, journals, previous research, magazines, or electronic media. This secondary data is collected by means of literature studies which then complement each other and correct. The location of this research was conducted at the Office of the Forest Management Unit (KPH) Maria Donggomasa Bima, Bima City Police Office, and the District Court (PN) Raba Bima. For field research areas conducted in Bima City and Regency Data analysis techniques begin using triangulation. The application of the concept of triangulation to direct the final results of this study in the form of information is then connected with the perspective of theory in order to avoid the subjective knowledge of researchers of research facts, In other aspects the concept of triangulation can also direct a deep understanding of the theoretical knowledge of the results of data analysis that has been obtained. The connection with the court's decision will be connected with field data, and the results of interviews with law enforcement or informants who are then conceptualized as researchers' findings.

\section{Result and Discussion}

\subsection{Overview of Perpetrators of Illegal Logging Crimes in Bima NTB}

Secara geografis wilayah Bima Nusa Tenggara Barat (NTB) consists of Regencies and Cities. where the two wilayah are located at the eastern end of West Nusa Tenggara province (NTB), the area of Bima Regency is about 4,394.38 km2 and there are 18 subdistricts consisting of 191 villages and 419 hamlets. While the area of Bima City amounted to $222.25 \mathrm{Km} 2$ which consists of 5 district namely district Rasa Na'e Barat, Rasa Na'e Timur, Asakota disricti, district Mpunda and Raba. (Local Government, n.d.)

Bima regency is categorized as having a high enough mountain including mount Tambora, mount wera, wawomountain, donggo mountainand lambitu mountain bima regency,the restis lowland, rice fields as well as dry land. Based on datareleased by the Office of Environment and Forestry (LHK) in 2017 about forest areas according to function and their uses such as protected forests, conservation forests, natural caga $r$ forests, forests fixed production and limited production forests as seen in Tabel.1 below:

Table 1. Area of Kota / Regency ForestArea based on function

\begin{tabular}{lcccccc}
\hline Kota/Regency & H.hedging & CA & TWA & H.Elevation & HPTP & HPTB \\
\hline Bima City & 3.280 ha & - & - & - & 1.258 & 1.497 \\
\hline Bima Regencv & 83.189 ha & 21.095 & 232 & 55.600 & 44.740 & 6.686 \\
\hline
\end{tabular}

Source: Department of Environmentand Forestry, 2017

Departing from the. 1 table data above bahwa protected forest area in the city of Bima about 32,80 hectares while for the fixed production forest luasnya about 1,258 hectares and limited production forest about 1,497 hectares. Comparison with bima regency forestarea looks different where the area of protected forest area in Bima Regency reaches 83,189 hectares, nature reserve forest area covering 21,095 hectares, natural park forest area of 232 hectares, conservation forest area of 55,600 hectares, fixed production forest area of 44,740 hectares and limited production forest area of 66.86 hectares.

Forestareas in the Bima region with definitive figures of 217,586 hectares mostly switched status to critical land and deforested forests, the conditionof the deforested forest itself there is naturally bald there are also bald caused by human activities such as the habit of taking wood,the clearing of forest areas for agricultural land and the transfer of forest functions and the high demand for logs by companies both local companies and companies outside the Bima area. From various studies to the exploitation carried out by humans certainly make the forest can 
not function optimally even in the dry season the forest area that has been cut down will look dry,rocks and shrubs that look yellow. Based on the observations of researchers, the forest damage in Bima does not occur in one district only but this forest damage occurs in various villages both in Wawo, Langgudu, Madapangga, Lambitu, Belo, and Parado district. Bima Regency.

According to A. Hamid as Secretary of Tarlawi Village, Wawo DistrictBima "many people here when finished harvesting their corn in and out of the protected forest aim to take wood to sell to entrepreneurs". Interview results, June 14, 2021, at 08:56 Wita). The statement of the Secretary of Tarlawi Village, in line with what hartoyo, one of the residents of The Langgudu Village of Bima Regency, stated that "the people of the rate began cutting down sonokling type wood since the peak of 2015 in 2017 . The wood is sold to retailers with a cubicationcount, while the retailers are from the police, entrepreneurs, there are also from ordinary people" Interview results, June 16, 2021. At 3:30 p.m.).

Bsome of the district identified patterns of forest destruction behavior is almost the same, such as the habit of opening protected forests to be converted into agricultural land, as well as the habit of cutting down wood and selling wood illegally. If categorized, there are 2 (two) groups that commit illegal logging in Bima, including community groups and business groups.

\section{a. Community Group (Community group)}

Community groups are elements of important that play an active role inprotecting forest destruction, meaning that not all peopledo the same as stealing and cutting wood but there are some groups of people who live on the edge of the forestplaying an active role in illegal logging, both group-by-person. As for the logging equipment that is often used by this group in the form of chain machines (gasoline-poweredportable saws), ordinary saws, machetes, kapak,and a variety of equipment. Other traditional. Wood that has been cut down will be transported using trucks, containers, Pic-ap and motorcycles, some of which are in their own homes there are also directly to the company's shelter or directly to the port of Bima (Mbojo). .

If associated with social crime theory the most decisive influence of a person or group of people committing a crime is an external factor that arises from this perspective social force considering the relationship between society and crime. (Salam, 2020) Where evil occurs when humans feel abandoned and poor, even in this condition humans can do anything to meet theirneeds, (Dulkiah,2020)

\section{b. Employers Group(Business group)}

The group is a group engaged in business and trade in special trade(export-import) outside the Bima area, the mode of crime played by this group can be in the form of data manipulation and moving community groups, where the community is directed. to do logging then offer a price with a fairly high market. This is said by Dirman, one of the residents of The Langgudu Village of Bima Regency who was directly involved inthe case of sonokling logging in the stone river forest area or called So Nonggo Tende (name offorestarea) Of Lane Village, Dirman stated " in 2017-2020 which became the center of logging activities of the community at the exact rate in the forest area of the So Nonggo Tende rock river bordering the forest area of Ngali Village, and Diha district Village of Belo Bima Regency. This forest area is a protected forest area that has hundreds of hectares of sonoklingtype wood" early mula occurrence of logging because there is an issue developed by the local community that there are retailers and wood users outside bima area offering a fairlyhigh price of wood. (Interview results, June 12, 2021, 10:20 pm)

In this phase I sometimes the community is used or utilized by certain groups of people, there are even some community groups that act as beking where this group protects illegal logging activities, people who become some of the thugs, there are also prominentpeople. (Safrin Salam, 2020)The strength and control of this group is quite massive and organized, the political diplomacy they build certainly affects the public policy of political management is not doing physical actions such as cutting down wood or transportingwood but thisgroup becomes intellectual actors and actors. Intersect with public officials, politicians, corporate affiliations, and cooperate with police officers.

Nature criminology perspective that "individual actors are individuals while corporate/business actors are people or groups of wealth that are organized either a legal entity or not. legal body. The model of crime played by this group is a series of open crimes meaning that this crime is committed in a certain way based on a certain order (order), this type belongs to the professional class , big capital and the marketing 
is quite broad. While closed crimes are carried out through the exploitation of illegal, these crimes are widely committed by companies with a pattern of shyness and manipulating documents, letters and documents. otherthings, as if the document is valid and original" (Nurhadiyanto, 2016)

\subsection{Prevention of Illegal Logging in Bima NTB}

Pthere is a principle of prevention against criminal acts can be conceptualized as the core of the law enforcement process where the vision of law enforcement is described in the values and norms of law to be able to create order, order and can create peace in social life. "Law enforcementand the implementation of criminal law aim to prevent, maintain and improve the legal system of penal applied by the state"(Tonry \& Farrington, 1995)

Pencegahan criminal acts of illegal logging (illegal logging) by law enforcement inthis case Police/ Civil Servant Investigators (PPNS),BalaiKesatuan Pengelolaan Hutan (KPH) or Local Government (Pemda) has authority and role of masing-ng-each to conduct prevention through the formation and formation of good and law-abiding community character.

In law No.18 of 2013 concerning the Prevention and Regulation of Forest Destruction has been in the form of the name of the ForestDestruction Prevention and Development Agency or abbreviated as LP3H, Ip3h institution is a special institution that is authorized to carry out criminal acts of forest squabbling, LP3H also serves to carry out investigation, prosecution. both through the judicial and out of justice. Responding to the degradation and deforestation of hutsin the NTB region, the Ntb Provincial Government, forming the name satuan Tugas(Task Force) prevention and eradication of forest destruction, this is contained in the Decree (SK) of the Governor of West Nusa Tenggara (NTB) Number: $522-205$ of 2018 concerning Task Force (Task Force) prevention and eradication of forest destruction of West Nusa Tenggara Province (NTB)consisting of the Governor of West Nusa Tenggara, NTB Provincial LHK Office, TNI, NTB Police Chief, NTB High Court and NTB High Prosecutor. The operation control task force consisted of Kodim 1608 Bima, Bima City Police Chief, Forestry Police, District/City Pp Police Unit, BKSDA Bima and KPH Hall se-NTB.

The measures of the governmentor law enforcement in preventing the criminal act ofillegal logging in Bima are as follows:

\section{a. Prevention of Pre-Emtif}

Pre-emtive prevention is one of the earliest forms of prevention before the occurrence of criminalacts, meaning that this pre-emtive approach will be an instrument for law enforcement to internalize the norms and rules ofthe lawin everyone. (Arifin, OsgarS. Matompo, 2021). Looking at the Decree (SK) of the Governor of West Nusa Tenggara (NTB) Number: 522-205 of 2018 concerning the Task Force (Task Force) on prevention and eradication of forest destruction of NTB Province, it was explained that pre-emtif prevention efforts among them did socialization and counseling, fostering and shaping environmentally conscious communities, installing prohibition boards and establishing coordination between district/ city governments including camat and village government.

The results of the interview with Pak Ahyar as the Head of KPH Maria Donggomasa Bima showed that "oneof the activities that are non-physical is carried out by KPH Hall, namely the greening activities of deforested forests or dry land that are held in the cross-sectoral program in 2021 in Tolo Uwi district Village of Monta Bima Regency. In this activity, the KPH Hall also involves related agencies including community elements". (Interview,June 30, 2021, 8:30 a.m.)

The purpose of legal extension itself is to improve the understanding of the community so that the public knows and understands how important the care of the function of the forest as a buffer for human life, in other aspects of this extension is part of the character of the community in forming compliance and obedience to the law so that in the future the community is no longer involved in harmful crimes. self-harm or harm tomany people.

\section{b. Preventive Prevention}

Preventive measures are the initial action taken by law enforcement before the occurrence of a crime or criminal act, preventive is a further action of the pre-emtif step where preventive measures are carried out before the occurrence of a crime or crime. Criminal acts means preventive measures are efforts made by law enforcement to eliminate or eliminate the atmosphere of crime or the opportunity of someone to commit a 
crime. The most important action can be done by patrolling, or mapping protected forest areas that are considered prone to illegal logging.

Lembanga pelaksana apartfrom the TNI and Police based on Regional Regulation (Perda) Number 13 of 2014 concerning the organization and working arrangements of other institutions as part of the regional device of West Nusa Tengga Province (NTB) including KPH maria Donggomasa,KPH Tambora and KPH Ampang Riwo Soromandi Provinsi Nusa TenggaraBarat(NTB), the function of the institution to perform pola recovery back for forest destruction then invite community and build partners with indigenousleaders, communities, youth or with community organizations, then perform reforestation simultaneously in order to overcome the occurrence of disasters. prolonged nature.

\section{c. Repressive Prevention}

Article 1 of the Criminal Procedure Law (Criminal Code) investigator is the person who performs the investigation, while the investigation is a series of actions carried outby investigators to determine, and determine a criminal event, whether from the event there is a criminal act or notif there are allegations. There is a criminal act, then the investigator will conduct further investigation to find elements of the criminalact. (Marsela, 2016). Law No.18 of 2013 on Prevention and Eradication of ForestDestruction (P3H), became the basis for Police Investigator /PPNS Forestry in carrying out the investigation function in the field of forestry.

The criminal act of illegal logging is specifically regulated in Law No. 18 of 2013 on P3H, as stated in the Criminal Code the crime of illegal logging is understood as an act that has an element of general criminal offense, which then Classified into common forms of crime including smuggling, forgery, embezzlement, destruction and detention. For the stage of investigation based on the provisions of The Criminal Code Article 7 paragraph 2 of the Criminal Code that Civil Servant Investigators (PPNS) under the supervision of the Police Investigator of the Republic of Indonesia (Polri)whose actions includes investigations, investigations, arrests, detentions, prosecutions and examinations in the fund.

Based on the results of an interview with Mr. Suherman as a member of the Bima Kota Police Tipidter Kanit that repressive steps oleh law enforcement in preventing the occurrence of illegallogging crimes in Bima, First, Security operations around illegal logging forestareas, Second, determine the target of the operation (TO) and further investigation related to the alleged criminal acts of illegal logging, Third, collect evidence in the form of chainsaws, chain machines, axes, trucks (transport cars) or property belonging to suspects of illegal crimes. logging. (Interview results, July 14, 2021,1:30 p.m.)

Cases handled by bima kota police in 2015-2020 include first, the case of transporting wood tampa legal documents, this case involves the initials FD from West Naru Village district Sape Bima Regency with Police Report/ K/ 12 / II / 2015 / Res Bima Kota.dated February 25. 2015. Second, the case of storing or owning wood forest products originating from protected forest areas, this case involves the initials RD from Maria district Wawo Village of Bima Regency with LP / K / 243 / II / 2016 / Res Bima Kota, Dated June 8, 2016. Third, the case of transporting tampa wood documents SKSHH by the initials brother IR from Wane Village. The care of The Bima Regency Parado with LP/K/12/l/2017/Res Bima Kota. November 21, 2017. Fourth, the case of transporting sonoklin woodas much as 3 truk Container tampa Valid documents, this case involves the Director of UD Ridho district Wera Bima Regency with LP / K / 256 / II / 2020 / Res Bima Kota. February 26, 2020.

\subsection{Model of Accountability of Business Actors Who Commit Illegal Logging In Bima}

The term businessman itself is understood as part of the activities of individuals who move their energy and mind for a purpose such as work or activities engaged in the field of trade and solely to seek support, (Setiawan, 2021). In Article 1 paragraph (3) of Law No. 18 of 1999 on consumer protection explained that business actors are every individual who carries out economic activities or who is engaged inthe field oftradeand commerce. Individual people in this case can be legal entities or not legal entities such as companies,SOEs, cooperatives, traders, distributors, etc.

Another term of legal nor non-legal entity is a corporation in Law No. 18 of 2013 on Prevention and Eradication of Forest Destruction mentioned that corporations are a collection of people or wealth organized either in the form of legal entities or not legal entities, but in fact the corporation will not move tampa there are business actors, entrepreneurs oreconomists who move it. Because crime currently involves many business actors / corporations, the provisions of corporations/business actors as the subject of criminal law are regulated 
specifically in Law No. 41 of 1999 about forestry Jo. Uu No. 18 of 2013 on Prevention and Eradication of Destruction of Hut an, further regulated in the Regulation of the Supreme Court (Perma) of the Republic of Indonesia Number 13 of 2016 on The Regulation of How to Handle Criminal Cases by Corporations.

Between legal entities and not legal entities there is a difference where this legal entity is referred to as a limited liability company entity (Pt), cooperatives, foundations, SOEs, corporate companies(persero)and public companies (perum). While the entity that is not a legal entity, consists of trading businesses, trading companies, firms, and komanditer (CV) alliances. (Yohana, n.d.). Seeing a very striking difference between legal entities and open legal entities, the form of legal responsibility for business actors / corporations who commit criminal acts. First, absolute liability (strict liability) that imposes on the actions committed by the leadership, directors, members or administrators of the corporation. Second, vicarious liability that focuses on the company's leadership, crane, or director, in the sense that the company's imponent must be held accountable for mistakes made by subordinates or their curry. According to Dobson, the two concepts of accountability are more precisely for business actors who are legal entities and are not appropriate for business actors who are not le gal entities,(Dobson, 2008).

The concept of absolute liability (strict liability) and vicarious liability, is also regulated in Law No. 18 of 2013 and in Article 109 paragraph (1) itis mentioned that "nature the actoflogging, harvesting, harvesting, mastery, transportation and circulation of timber resulting from illegal plunders carried out by or on behalf of a corporation criminal charges and/or criminal convictions" carried out against the corporation or its managers" while the model of legal liability for business actors who do not have a legal entity is still charged to individual people because the director is only himself and works alone or uses his own capital without there is a separation of wealth with business entities y He's running.

The liability of non-incorporated business actors or businesses that are run by individuals can be seen in the Decision of the District Court (PN) Raba Bima with Number:231 / Pid.B / LH / 2020 / PN RBI dated June 17, 2020 in the first alternative indictment pn Raba Bima sentenced the initials of the accused. TF, because this TF is a business actor whose nature is an individual or business in its own run, the provision in the hakim ruling refers to Article 88 paragraph (1) letter a Jo. Article 16 of Law No. 18 of 2013 on Prevention and Eradication of Forest Destruction. Where in Article 16 mentioned "every person who transports wood forest products must have a document that is a certificate of legal forest products in accordance with the provisions of the lawsand regulations, further Article 88 paragraph (1) letter a, mentioning that "orangpeeorangan who deliberately carrying out the transportation of forest products without having documents that are legal certificates of forest products in accordance with the provisions of the laws and regulations.

The basis of the judge's consideration in the ruling, First, intentionally carrying out the transportation of forest timber without having documents that are legal certificates of forest products in accordance with the provisions of the laws and regulations, Second, loading forest products or bringing forest products into conveyances and conveyances that bring forest products moving to their destination and dismantle, degrade, or Removing forest products from transport equipment, Third, the defendant's actions do not support government programs in Forest Destruction Prevention and Eradication. Based on that consideration, the judge imposed a criminal sentence against TF's conviction in the form of imprisonment for 1 (one) year 6 (six) months anda fine of Rp. 500,000.00 (five hundred million). rupiah) with the provision if the denda is not able in bayar it will be replaced with a criminal cage for 3 (three) months.

Judging from the chronological case as described in the indictment by the Public Prosecutor that the defendant TF on February 19, 2020 at 19:00 Wita contained wood sonokling type peer 59 (fifty nine) milestones with a volume of $12,329 \mathrm{M}^{3}$ tedakwa TF using a tronton truck with the number Pol.Z9712 HB, the purpose of which will be sent to brother AR as Director of CV. Araya Group located in Bondowoso East Java. At first the woodwasimpan in the warehouse owned by BK as Director of UD. New appears in Nata Village Palibelo District Bima, while the wooden list document oland along with documents transporting legal information of forest products of TF defendants in love by sister HW as Director of UD. Kaliandra Bima City which in the end the document is not legally recognized because it is not number and signature of the competent official. According to the author that in this case notonly involving TF brothers butalso involving brother BK Dirut UD Muncul Baru and sister HW Dirut UD. Kaliandra. 


\section{Conclusion}

Based on the results of the research and discussion above can be concluded, First, as acriminal act of illegal logging in Bima NTB can be classified into 2 (two) groups, namely community groups (Community groups) and business groups, where This community group acts as loggers and then the timbers are sold to business people engaged in trade and timber business, while the group of entrepreneurs will facilitate illegal logging activities such as promising high prices, providing logging equipment, and providing cars to hold wood even logging groups. Companies also often send wood from Bima outside the area where the delivery process uses ways that are contrary to the law. Second, the form of prevention carried out by law enforcement in the form of presemimeasures, preventive measures and repressive measures. Third, the model of legal responsibility for business actors specifically business actors who are not legal entities or business entities run by individuals, of course, based on the principle oferror where PN Raba Bima with Number: 231 / Pid.B / LH / 2020 / PN RBI dated June 17, 2020 imposes a prison sentence for 1 ( one) year 6 (six) months to the initials TF with the element of intentionally transporting wood products withouthaving valid documents.

As for the advice in this study, First, improve the development of community law or legal extension of minimal 1 time in one month both by BKPH in each district as well as the Police and TNI, Second, improving thestrategy management process (strategic management). process) nature aspects of environmental analysis, then determine the stages of policy formulation, strategy implementation and strategy evaluation. Furthermore, regular checks and checks on forests that become prone to illegal logging and encroachment of agricultural land. Third, in cases or cases that are done together will be the subject of consideration, investigators, prosecutors and judges to prove the existence of criminal acts of inclusion.

\section{References}

Absori. (n.d.). Penegakan hukum lingkungan pada era reformasi. Jurnal IImu Hukum, 8(2), 221-237.

Amoah, M., \& Boateng, R. K. (n.d.). Addressing illegal logging in Ghana: Do value, social identity, and corporate social responsibility theories matter? International Forestry Review, 16(6), 524-536. https://doi.org/10.1505/146554814814095285

Anjari, W. (2016). Pertanggungjawaban Korporasi Sebagai Pelaku Tindak Pidana. Jurnal IImiah Widya Yustisia, 1(2), 116-121.

Arifin, Osgar S. Matompo, A. M. B. (2021). Penanggulangan Tindak Pidana Illegal Logging di Sulawesi Tengah Illegal Crime Prevention Logging in Central Sulawesi. Jurnal KolaboratifSains, 04(5), 234-240.

Butler, R. A. (2020). How Much rainforetls Being Destroyed.

Candra, S. (2020). International Journal of Research in Commerce and Management Studies. International Joumal of Research in Commerce and Management Studies, 2(03), 37-50.

Dobson, P. (2008). Criminal Law (Eight Edition). London : Thomson Sweet and Maxwell.

Dulkiah, H. M. (2020). Sosiologi Kriminal. Bandung:LP2M UIN SGD,.

Febrianto, G. D. (2019). Strategi Indonesia -RRT Dalam Memberantas Illegal Logging Tahun 2009 -2014. Joumal of International, 5(2), 332-340.

Flejzor, L. (2005). How The ITTO Addresses Illegal Logging by. Chatham House.

Hari Sutra Disemadi, N. S. P. J. (2019). Perkembangan Pengaturan Korporasi Sebagai Subjek Hukum Pidana Di Indonesia. Jurnal Hukum Media Bhakti, 3(2), 118-127. https://doi.org/10.32501/jhmb.v3i2.80

Imron Rizki, Safrin Salam, A. M. (2019). Menguji Eksistensi Pengadilan Agama Dalam Menyelesaikan Sengketa Ekonomi Syariah. Indonesia Journal of Criminal Law, 1(1), 65-76.

Marsela, S. (2016). Penyidikan Terhadap Tindak Pidana Perambahan Kawasan Hutan Cagar Biosfer Giam Siak Kecil Oleh Kepolisian Resor Bengkalis Berdasarkan Undang-Undang Nomor 18 Tahun 2013 Tentang Pencegahan Dan Pemberantasan Perusakan Hutan. JOM Fakultas Hukum, 3(2), 1-15.

Nurhadiyanto, L. (2016). Alur pelacakan pembalakan liar (Illegal Logging) Melalui Pendekatan Pencucian Uang. Sisilainrealita, 1(2), 37-38. 
Pemda. (n.d.). Situs Resmi Pemerintah Kabupaten Bima. Wikipedia.Org. Kabupaten. Bima. Retrieved from https://id.wikipedia.org/wiki/Kabupaten_Bima

Safrin Salam, D. (2020). Perkembangan Filsafat Hukum Kontemporer. Zifatama Jawara. Retrieved from https://books.google.co.id/books?id=Rf7_DwAAQBAJ\&dq=+safrin+salam+filsafat+hukum\&lr=\&hl=id\&sourc e=gbs_navlinks_s

Salam, S. (2020). Rekonstruksi Paradigma Filsafat IImu :Studi Kritis Terhadap IImu Hukum Sebagaillmu. Ekspose: Jurnal Penelitian Hukum Dan Pendidikan, 18(2), 885-896. https://doi.org/10.30863/ekspose.v18i2.511

Setiawan, E. (2021). Kamus Besar Bahasa Indonesia (KBBI) :

Tonry, M., \& Farrington, D. P. (1995). Strategic Approaches to Crime Prevention. Crime and Justice, 19(1), 1-20. https://doi.org/10.1086/449228

Wirya, A. (2015). The Criminal Policy Formulation At Law Enforcement Penal Forestry. Jurnal IUS: Kajian Hukum Dan Keadilan, 3(7), 19-41.

Yohana. (n.d.). Tanggung Jawab Hukum Atas Bentuk Usaha Badan Hukum Dan Bentuk Usaha Non Badan Hukum. Jurnal Mercatoria, 8(1). 